\title{
Bacteriological and physico-chemical assessment of untreated drinking water used by residents in Ofougbene- Izon-Borotu Community, Delta State
}

\author{
Otajevwo Dafinone Festus * and Dio Princess Tamaramiene \\ Department of Microbiology, Western Delta University, Oghara, Nigeria.
}

Publication history: Received on 14 May 2020; revised on 22 June 2020; accepted on 13 November 2020

Article DOI: https://doi.org/10.30574/gscarr.2020.5.2.0036

\begin{abstract}
This study was aimed at assessing the bacteriological and physio-chemical qualities of the ground well water which is the only available drinking water to residents of Ofougbene community of Burutu Local Government Area, in order to check it's fitness for drinking and evaluate the awareness of the people about dangers of drinking untreated water. Seven water samples coded Station1-Station 7 were obtained from seven different ground wells in the study area. Bacteriological assessment was done by Most Probable Number (MPN) technique while physical, chemical and organic analyses of the water samples were carried out by known standard methods. Bacterial organisms isolated were Escherichia coli, Klebsiella pneumoniae, Enterobacter aerogenes and Staphylococcus epidermidis. All ground water samples contained total aerobic bacterial load ranging from $1.8 \times 10^{3}$ to $7.0 \times 10^{3} \mathrm{CFU} / \mathrm{ml}$. The mean \pm standard deviation values of $\mathrm{pH}$, electrical conductivity, color, turbidity, Total Dissolved Solids, Suspended Solids, alkalinity, chloride, hardness, phosphates, nitrates, sulphates, calcium, magnesium, Dissolved Oxygen and Biological Oxygen Demand were: $5.8 \pm 16.43,51.4 \pm 27.0 \mathrm{uS} / \mathrm{cm}, 22.4 \pm 12.32 \mathrm{mg} / \mathrm{l}, \quad 11.8 \pm 5.14 \mathrm{mg} / \mathrm{l}, 28.4 \pm 15.10 \mathrm{mg} / \mathrm{l}, \quad 3.8 \pm 3.80 \mathrm{mg} / \mathrm{l}$, $15.4 \pm 12.49 \mathrm{mg} / \mathrm{l}, 21.12 \pm 0.02 \mathrm{mg} / \mathrm{l}, 53.3 \pm 32.72 \mathrm{mg} / \mathrm{l}, 0.20 \pm 0.04 \mathrm{mg} / \mathrm{l}, 2.77 \pm 0.27 \mathrm{mg} / \mathrm{l}, 9.28 \pm 3.60 \mathrm{mg} / \mathrm{l}, 11.9 \pm 12.10 \mathrm{mg} / \mathrm{l}$, $1.7 \pm 0.51 \mathrm{mg} / \mathrm{l}, 5.9 \pm 0.58 \mathrm{mg} / \mathrm{l}$ and $3.04 \pm 0.51 \mathrm{mg} / \mathrm{l}$ respectively for all the water samples assessed. Whereas water quality status for all samples was unsatisfactory, water quality concern was high. Compared to reference values provided by Standard Organization of Nigeria (SON) and presence of pathogens, we conclude that the ground water used by the people of the community is unfit for human consumption. This is for the immediate attention of the Public Health Authorities of both the LGA concerned and the Delta State Government.
\end{abstract}

Keywords: Bacteriological; Physic-Chemical; Assessment; Untreated; Water; Ofougbene; Community.

\section{Introduction}

Water pollution is one of the most pervasive problems afflicting people throughout the world. Waterborne illnesses and multiple epidemics are connected to the consumption of contaminated or inadequately treated water. Scientific data and evidence on the role of waterborne pathogens in the epidemiology of hospital-acquired infections are insufficient [1]. Recent reports on identified water borne pathogens have provided novel insights into the understanding of the pathology and effects of diseases which persist in numerous aquatic systems due to the advantage of resistance to various environmental factors $[2,3,4,5]$.

Health facilities, mainly health care centers, hospitals, clinics and laboratories pose higher risk of water contamination since these are more likely to be the sources of viral and bacterial pathogens [6, 7]. Although numerous researches have been conducted to address the detection and origin of pathogens in both drinking water and wastewater [8], September et al. [9] however, reported that insufficient studies have been done explicitly about tracing the occurrence of pathogens in water sources near healthcare facilities $[10,11]$.

\footnotetext{
${ }^{*}$ Corresponding author: Otajevwo Dafinone Festus

Department of Microbiology, Western Delta University, Oghara, Nigeria.
} 
For all living organisms, water is the most vital and important factor of survival. Inadequate access to clean water, inappropriate water treatment and bad sanitation systems is one of the most pervasive issues distressing people throughout the globe, causing waterborne infectious diseases which are responsible for approximately 10 million deaths per year $[1,12,13]$. Human health is prone to microbial risks caused by enteric viruses and bacteria. Studies have shown that contaminated drinking water has been a source of several critical diseases such as diarrhea, nausea, cholera, typhoid, dysentery, abdominal pain and food poisoning. The situation is even worst at health care centers where drinking water is a source of pathogen transmission owing to negligence of managerial authority towards supplying properly treated water. Variant pathogens have been observed in ground and surface water, flood and dam water $[14,15,16]$. Furthermore, presence of bacterial pathogens is associated with physico-chemical characters and location of drinking water sites [15].

The justification of this work is hinged on the indiscriminate use of untreated groundwater for drinking by residents of Ofougbene-Izon-Borotu community due to the unavailability of treated source of water supply. The aim of this study therefore, is the bacteriological and physio-chemical assessment of ground water used as drinking water by the residents of the community under study with the following objectives:

To determine the bacteriological quality of drinking water in the community.

To determine the source of some common diseases in the community

To enumerate the microbial load of the well water samples analysed.

To enumerate the physiochemical parameters of the well water.

\section{Material and methods}

\subsection{Study area}

This study was carried out using water samples from Ofougbene-izonborotu town, Burutu L.G.A, Delta state, Latitude $5^{0}$ $21^{\prime} 11.81^{0} \mathrm{~N}$, Longitude $5^{0} 30^{\prime} 29.74^{\circ}$. Water samples were collected from strategic ground wells which the community uses domestically including water used for drinking, cooking, and sanitary purposes. Seven (7) samples from different locations in the community were collected as follows;

Sample1- Labodo Zion grounds, Izon-borotu

Sample 2- Leomoni quarters, Izon-borotu

Sample3- Leomoni 1, Ibama well, Izon-borotu

Sample 4- Azenaware 1 quarters, Izonborotu

Sample 5- Azenaware2 quarters, Izon-borotu

Sample 6- Ere-ebisingha quarters, Izon-borotu

Sample 7- Azaneware 3 quaters, Izon-borotu

\subsection{Collection of samples for water analysis}

Samples of water for bacteriological testing were collected in sterile bottles and taken directly to Microbiology laboratory, Western Delta University, Oghara for processing. This was to prevent accidental contamination of the water during and after its collection.

\subsection{Sampling/ Bacteriological testing of water samples}

A sterile bottle was held by the base in one hand and the other hand was used to remove the stopper and cover together. The stopper and cover were retained in the hand while the bottle was filled with groundwater from each of the seven groundwater wells in the study area. To prevent contamination, care was taken not to touch the screw thread of the 
bottle neck or the inside of the cap. One bottle was used for one sample. When a bottle was found to have been contaminated, it was not used (i.e was discarded).

\subsection{Multiple Tube Technique/Most Probable Number (MPN)}

The Multiple Tube Fermentation technique as described by Collins and Lynne [17] and Mackie and McCartney [18] was used to estimate the concentration of viable total coliforms (TCs) and thermotolerant Escherichia coli per $100 \mathrm{ml}$ of each water sample. After incubation, the number of bottles in which lactose fermentation with acid and gas production had occurred was counted and recorded. The lactose was fermented by the coliforms in the water samples (if present) while the bile salts inhibited all Gram positive bacteria allowing only Gram negative bacteria such as coliforms and Escherichia coli to thrive. By reference to Probability Tables, the most probable number of coliforms in $100 \mathrm{ml}$ water sample was estimated [19].

Each bottle of lactose broth contained an inverted Durham tube for the collection of gas. This was added before the broth was sterilized making sure that the inverted tube was full of broth and there was no air bubble inside it. If any air bubble was trapped in the tube, the bottle was inverted to allow the bubble to rise out of the tube.

This technique is divided into presumptive, confirmatory and completed tests.

\subsection{Presumptive test}

Each bottle was labeled with a sample code number. The bottle cap and cover were removed and the mouth of the bottle flamed, the bottles were inoculated with MacConkey broth. Single strength and double strength MacConkey broths were prepared by dissolving $40 \mathrm{~g}$ and $80.14 \mathrm{~g}$ of the medium respectively in $1000 \mathrm{ml}$ of distilled water and sterilized in an autoclave at $121^{\circ} \mathrm{C}$ for 15 minutes. Preparation of the broth strengths was as follows: $50 \mathrm{ml}$ of water sample was added to the bottles containing $50 \mathrm{ml}$ of broth. Using sterile pipettes, $10 \mathrm{ml}$ of sample water was added to each of the five bottles containing $10 \mathrm{ml}$ of broth while $1 \mathrm{ml}$ of each water sample was pipetted into each of the five bottles containing $1 \mathrm{ml}$ of broth with inverted Durham tubes added into broth containers before inoculation. The inoculated broths were incubated in an incubator at $37^{\circ} \mathrm{C}$ for 24 hours with the bottles properly capped. After incubation, inoculated bottles were counted and examined for production of both acid and gas. The protocol used is shown below:

\begin{tabular}{|l|l|l|l|}
\hline No. of bottles per sample & 1 Bottle & $\mathbf{5}$ Bottles & $\mathbf{5}$ Bottles \\
\hline Volume of broth in samples & $50 \mathrm{ml}$ double strength & $10 \mathrm{ml}$ double strength & $1 \mathrm{ml}$ single strength \\
\hline Volume of sample water & $50 \mathrm{ml}$ & $10 \mathrm{ml}$ & $1 \mathrm{ml}$ \\
\hline
\end{tabular}

Note Acid production was shown by a change in color of the bromocresol indicator in MacConkey broth from purple to yellow and gas production by the collection of a bubble or space in the upper end of the Durham tube. MacConkey broth containing neutral red was not used due to its inhibitory effect on Escherichia coli.

\subsection{Confirmatory test}

For the differential coliform test (or Confirmatory test), each MacConkey tube showing acid and gas (from Presumptive test) was then subcultured into a fresh tube of MacConkey broth and incubated at $44^{\circ} \mathrm{C}$ for $24-48$ hrs. Formation of gas within 48 hours is practically specific for Escherichia coli and indicative of faecal pollution of the original water sample.

\subsection{Completed test}

After incubation of inoculated differential test broth, positive bottles showing acid production (ie change of indicator colour from purple to yellow) and gas production (ie, presence of space at top end of Durham tubes) at $44^{\circ} \mathrm{C}$ were then subcultured onto prepared sterile MacConkey agar and Eosin Methylene Blue agar plates. The isolates were inoculated into prepared sterile peptone water and incubated overnight to carry out characterization and identification tests. Specific tests for coliforms, Escherichia coli and other indicator organisms were carried out. 


\subsection{Total Heterotrophic Bacterial Enumeration}

Having confirmed presence of specific indicator organisms, their microbial load enumeration was carried out by tenfold serial dilution. Using serial dilution of 10 - fold, $1 \mathrm{ml}$ of each water sample was diluted into 9 ml of sterile normal saline and dispensed into 10 test tubes ensuring that each dilution was properly mixed and $1 \mathrm{ml}$ from the last mixture or dilution was discarded. The resulting dilutions were $10^{-1}, 10^{-2}, 10^{-3}, 10^{-4}, 10^{-5}, 10^{-6}, 10^{-7}, 10^{-8}, 10^{-9}$, and $10^{-10}$. From each dilution, about two or three drops (equivalent to $0.02-0.04 \mathrm{ml}$ ) were plated out on Nutrient agar plates and incubated at $37^{\circ} \mathrm{C}$ for $24 \mathrm{hrs}$ for bacterial count. As a check, $1 \mathrm{ml}$ of each dilution was dispensed into sterile petri dishes into which $19 \mathrm{ml}$ of prepared sterile molten Nutrient agar was added [20]. Cultured plates were allowed to cool and solidify after which, they were incubated at $37^{\circ} \mathrm{C}$ for $24 \mathrm{hrs}$. Each dilution was plated in duplicate. At the end of incubation, colony forming units (CFM) were counted per ml of water sample and average count per dilution recorded. Only plates whose counts fell within 30-300 CFM/ ml were used [21, 22, 23].

\subsection{Determination of Physico-chemical Parameters}

Water samples were collected in sterile, clean sample containers and taken to the laboratory for physical and chemical analyses in line with SON guidelines [24]. Parameters analyzed included: pH, electric conductivity (EC), colour, turbidity, total dissolved solids (TDS), suspended solids (SS), alkalinity, chloride, hardness, phosphate, nitrate, sulphate, calcium, magnesium, dissolved oxygen (DO) and biological oxygen demand (BOD). The pH and colour were determined at the time of collection of samples using pH Meter and physical observation respectively while other parameters such as TDS, hardness, alkalinity, chlorides etc were determined in the laboratory using standard analytical procedures [25, 26, 27].

The results were compared against the standards for drinking water set by the Standards Organization of Nigeria (SON). The water quality index which is a numeric expression used to evaluate the quality of a given water body was calculated and used in the evaluation of the surface water quality. The index incorporates data from multiple parameters into a mathematical equation that rates the qualities of water bodies. The overall computation formula used to determine the water quality index is given as follows:

$$
W Q I=\frac{\sum \mathrm{qnWn}}{\mathrm{Wn}}
$$

\section{Results}

The microbial organisms isolated from the water samples are shown in Table 1. Four bacterial organisms were isolated from the water samples that were processed and included Escherichia coli, Klebsiella pneumoniae, Enterobacter aerogenes and Staphylococcus epidermidis. Escherichia coli occurred in water samples collected from all the seven sites, followed by Enterobacter aerogenes which occurred in 6 (85.7\%) sites, Staphylococcus epidermidis featured in 4 (57.0\%) sites while Klebsiella pneumoniae occurred in 3 (42.8\%) sites.

Table 1 Bacterial Organisms isolated from water samples

\begin{tabular}{|l|c|c|c|c|c|c|c|}
\hline $\begin{array}{l}\text { Organisms } \\
\text { Isolated }\end{array}$ & Station 1 & Station 2 & Station 3 & Station 4 & $\begin{array}{l}\text { Station } \\
\mathbf{5}\end{array}$ & Station 6 & $\begin{array}{l}\text { Station 7 } \\
\text { Percentage } \\
\text { occurence }\end{array}$ \\
\hline Escherichia coli & + & + & + & + & + & + & + \\
\hline $\begin{array}{l}\text { Klebsiela } \\
\text { pneumoniae }\end{array}$ & - & - & - & + & - & + & + \\
\hline $\begin{array}{l}\text { Enterobacter } \\
\text { aerogenes }\end{array}$ & + & + & + & - & + & + & + \\
\hline $\begin{array}{l}\text { Staphylococcus } \\
\text { epidermidis }\end{array}$ & - & + & - & + & + & + & - \\
\hline
\end{tabular}

Keys Station 1- Labodozion ground well, Izon-borotu; Station 2- Leomoni quarters dibe, Izon-borotu; Station 3- Leomoni 1 Ibama well, Izon-borotu; Station 4- Azenaware 1 quarters well, Izonborotu; Station 5- Azenaware2 quarters well, Izon-borotu; Station 6- Ere-ebisingha quarters well, Izonborotu, (+): Psresence of organism, (-): Absence of organism

The most probable numbers of Coliform bacterial organisms present in the water samples are presented in Table 2. 
The presumptive test results for water samples collected from all seven ground water sites showed that all MacConkey broths with Durham tubes contained gas. The most probable number (MPN) of coliforms per $100 \mathrm{ml}$ for the ground water samples ranged from 13 to $1600+$. Stations 1, 2, 3, 4, 5, 6 and 7 presumptively recorded coliform counts of 90 $\mathrm{CFU} / 100 \mathrm{ml}, 30 \mathrm{CFU} / 100 \mathrm{ml}, 17 \mathrm{CFU} / 100 \mathrm{ml}, 160 \mathrm{CFU} / 100 \mathrm{ml}, 22 \mathrm{CFU} / 100 \mathrm{ml}, 50 \mathrm{CFU} / 100 \mathrm{ml}$ and $13 \mathrm{CFU} / 100 \mathrm{ml}$ respectively. Values recorded for station sites 1, 4 and 6 were much higher than the recommended MPN value for drinking water which is 50 or less / $100 \mathrm{ml}$ [28]. In the order of level of contamination of ground water sampled from the sites, stations 4, 1, 6, 2, 5, 3 and 7 were so contaminated suggesting that the most and least contaminated drinking water sources in the community under study were groundwater collected from stations 4 and 7 respectively. The confirmed and completed tests yielded results which were true for coliforms. Colonies with pink sheen and a few blacks were observed on EMB agar and Gram staining revealed the bacteria to be Gram negative bacilli and positive to indole test and hence, suggesting thermotolerant Escherichia coli.

Table 2 Presumptive most probable number of coliforms in ground water samples under study.

\begin{tabular}{|c|c|c|c|c|c|}
\hline \multirow[t]{2}{*}{$\begin{array}{l}\text { Station } \\
\text { Site }\end{array}$} & \multicolumn{3}{|c|}{$\begin{array}{l}\text { Number of Tubes Showing } \\
\text { Positive Reaction Out of }\end{array}$} & \multirow[t]{2}{*}{$\begin{array}{l}\text { MPN/100 ml } \\
\text { sample }\end{array}$} & $\begin{array}{c}\text { СРСВ (2008) } \\
\text { Reference value }\end{array}$ \\
\hline & $50 \mathrm{ml}$ & $10 \mathrm{ml}$ & $1 \mathrm{ml}$ & & \multirow{8}{*}{$\begin{array}{l}\text { Maximum permitted } \\
\text { Coliform count for } \\
\text { drinking water } \\
=20-50 \mathrm{MPN} / 100 \\
\mathrm{ml}\end{array}$} \\
\hline 1 & 5 & 5 & 3 & 90 & \\
\hline 2 & 5 & 5 & 1 & 30 & \\
\hline 3 & 5 & 4 & 1 & 17 & \\
\hline 4 & 5 & 5 & 4 & 160 & \\
\hline 5 & 5 & 4 & 2 & 22 & \\
\hline 6 & 5 & 5 & 2 & 50 & \\
\hline 7 & 5 & 4 & 0 & 13 & \\
\hline
\end{tabular}

The total heterotrophic bacterial counts of the water samples from the water source drinking sites are presented in Table 3. Total aerobic plate count was performed to ascertain the overall bacteriological condition of the water samples. All ground water samples contained total aerobic bacterial load ranging from $1.8 \times 10^{3}$ to $7.0 \times 10^{3} \mathrm{CFU} / \mathrm{ml}$ (Table 3 ). While the highest viable bacterial load was detected in station site 4 , the least microbial load was recorded for station site 7. Station sites 2 and 3 recorded same load of $4.0 \times 10^{3}$ each while stations 1 and 5 recorded similar load of $2.0 \times 10^{3}$ each.

Table 3: Total Bacterial viable counts from ground water samples in OFOUGBENE-IZON-BOROTU community of Delta State.

\begin{tabular}{|c|c|c|}
\hline Water Samples & $\begin{array}{c}\text { Total bacteria viable counts } \\
\text { CFU/ } \mathbf{~ m} \mathbf{\times} \mathbf{1 0}^{\mathbf{3}}\end{array}$ & $\begin{array}{c}\text { Total bacteria viable counts } \\
\text { CFU/100 } \mathbf{~ m l}\end{array}$ \\
\hline Station 1 & 2.0 & 200,000 \\
\hline Station 2 & 4.0 & 400,000 \\
\hline Station 3 & 4.0 & 400,000 \\
\hline Station 4 & 7.0 & 700,000 \\
\hline Station 5 & 2.0 & 200,000 \\
\hline Station 6 & 2.3 & 230,000 \\
\hline Station 7 & 1.8 & 180,000 \\
\hline
\end{tabular}

Keys Station 1- Labodo zion ground well, Izon-borotu; Station 2- Leomoni quarters dibe, Izon-borotu; Station 3- Leomoni 1, Ibama well, Izonborotu; Station 4- Azenaware 1 quarters well, Izonborotu; Station 5- Azenaware2 quarters well, Izon-borotu; Station 6- Ere-ebisingha quarters well, Izon-borotu; Station 7- azaneware 3 quaters well, Izon-borotu 

Table 4 Results for physiochemical parameters in comparison to SON values

\begin{tabular}{|c|c|c|c|c|c|c|c|c|c|}
\hline \multirow{2}{*}{$\begin{array}{l}\text { Water quality } \\
\text { parameters }\end{array}$} & \multicolumn{8}{|c|}{ Stations } & \multirow{2}{*}{$\begin{array}{c}\text { Mean } \pm \text { Standard } \\
\text { Deviation }\end{array}$} \\
\hline & 1 & 2 & 3 & 4 & 5 & 6 & 7 & $\begin{array}{c}\text { SON } \\
\text { Standards }\end{array}$ & \\
\hline $\mathrm{pH}$ & 5.9 & 5.8 & 6.0 & 5.6 & 5.8 & 5.7 & 6.1 & $6.5-8.5$ & $5.8 \pm 0.16 .43$ \\
\hline EC (pt. Co) & 60 & 50 & 20 & 110 & 30 & 50 & 40 & 750 & $51.4 \pm 26.95$ \\
\hline Colour & 20 & 18 & 0 & 42 & 20 & 22 & 35 & 15 & $22.4 \pm 12.317$ \\
\hline Turbidity & 11 & 11 & 7 & 29 & 12 & 6 & 7 & 5 & $11.8 \pm 5.139$ \\
\hline $\begin{array}{l}\text { Total Dissolved } \\
\text { Solids }\end{array}$ & 31.8 & 26.5 & 10.6 & 58.3 & 24.3 & 35.6 & 11.5 & 500 & $28.4 \pm 15.064$ \\
\hline Suspended Solids & 3 & 3 & 0 & 12 & 3 & 6 & 0 & 5 & $3.8 \pm 3.829$ \\
\hline Alkalinity & 16 & 16 & 24 & 10 & 16 & 18 & 8 & 100 & $15.42 \pm 12.49$ \\
\hline Chloride & 21.12 & 21.12 & 21.12 & 21.12 & 21.12 & 21.12 & 21.10 & 250 & $21.12 \pm 0.002$ \\
\hline Hardness & 50 & 40 & 16 & 106 & 50 & 96 & 15 & 500 & $53.3 \pm 32.719$ \\
\hline Phosphate & 0.22 & 0.24 & 0.16 & 0.22 & 0.23 & 0.24 & 0.14 & 0.5 & $0.20 \pm 0.035$ \\
\hline Nitrate & 2.95 & 2.75 & 2.81 & 2.62 & 2.75 & 2.71 & 2.86 & 50 & $2.77 \pm 0.266$ \\
\hline Sulphate & 8 & 8 & 6 & 17 & 8 & 12 & 6 & 100 & $9.28 \pm 3.602$ \\
\hline Calcium & 18.44 & 4.81 & 1.60 & 38.48 & 6.92 & 11.34 & 1.80 & 75 & $11.9 \pm 12.095$ \\
\hline Magnesium & 1.46 & 1.46 & 1.46 & 2.43 & 1.46 & 2.64 & 1.26 & 0.20 & $1.7 \pm 0.512$ \\
\hline D. 0 & 5.2 & 5.5 & 6.5 & 6.0 & 5.5 & 5.8 & 6.8 & 7.5 & $5.9 \pm 0.576$ \\
\hline B. O. D & 3.0 & 2.8 & 3.8 & 3.1 & 2.8 & 3.0 & 2.8 & 6.9 & $3.04 \pm 0.510$ \\
\hline $\begin{array}{l}\text { Overall Water } \\
\text { quality index }\end{array}$ & 489.043 & 489.457 & 482.9399 & 482.939 & 811.678 & 489.577 & 867.795 & 419.314 & \\
\hline $\begin{array}{l}\text { Water quality } \\
\text { status }\end{array}$ & Unsatisfactory & Unsatisfactory & Unsatisfactory & Unsatisfactory & Unsatisfactory & Unsatisfactory & Unsatisfactory & Unsatisfactory & \\
\hline $\begin{array}{l}\text { Water quality } \\
\text { concern }\end{array}$ & High & High & High & High & High & High & High & High & \\
\hline
\end{tabular}

Interpretation of Data was based on: Nigerian Standards for drinking water quality (NSDWQ), SON (2007)

Note: The unit for all the parameters above is $\mathrm{mg} / \mathrm{l}$ except electrical conductivity and turbidity which were measured in $\mu \mathrm{S} / \mathrm{cm}$ and NTU respectively 
Table 4 shows the results of physical and chemical parameters for the water samples studied. The pH of all the water samples which ranged from 5.6-6.1 fell within the permitted limits of Standard Organization of Nigeria (SON) which is 6.5-8.5. Sample obtained from station 4 was most acidic while sample collected from station7 was least acidic. Water samples collected from all seven stations were clearly acidic. All the samples however recorded a pH mean standard deviation of $5.8 \pm 0.16$ which is still within SON acceptable limits. The electrical conductivity (EC) of samples $1,2,3,4,5$, 6 and 7 ranged from $20-110 \mu \mathrm{S} / \mathrm{cm}$ with a mean std deviation of $51.4 \pm 27.0 \mu \mathrm{S} / \mathrm{cm}$ and all recorded values did not exceed the maximum permissible limit of $750 \mu \mathrm{S} / \mathrm{cm}$. Turbidity values of samples 1 to 7 ranged from 7 - 29 NTU of which station 4 recorded the highest (29 NTU) while station 7 recorded the least (7 NTU) and all samples recorded a mean standard deviation turbidity value of $11.8 \pm 5.14$ NTU. Recorded turbidity values for each water sample exceeded the maximum permissible limit (MPL) set by SON [24].

The results of total dissolved solids (TDS) in samples 1 - 7 varied from $10.6-58.3 \mathrm{mg} / \mathrm{l}$ with a mean TDS standard deviation of $28.4 \pm 15.06 \mathrm{mg} / \mathrm{l}$ of which the highest TDS value was recorded by sample 4 (58.3 mg/l) and sample 3 recorded the least $(10.6 \mathrm{mg} / \mathrm{l})$. None of these values exceeded the MPL of $500 \mathrm{mg} / 1$ [24, 29]. The total suspended solids (TSS) of the water samples varied from $3-12 \mathrm{mg} / \mathrm{l}$ of which samples 3 and 7 did not record presence of TSS at all. The highest TSS value however, was recorded by sample 4 while the least was recorded by samples 1, 2 and 5 (each recording $3 \mathrm{mg} / \mathrm{l}$ ). With a mean TSS standard deviation of $3.8 \pm 3.83 \mathrm{mg} / \mathrm{l}$, only samples 4 and 6 values exceeded the MPL of $5 \mathrm{mg} / \mathrm{l}$. Alkalinity values for samples $1-7$ ranged from $8-24 \mathrm{mg} / \mathrm{l}$ with a mean alkalinity standard deviation of $15.42 \pm 12.49 \mathrm{mg} / \mathrm{l}$ of which the highest alkalinity value $(24 \mathrm{mg} / \mathrm{l})$ and least value $(8 \mathrm{mg} / \mathrm{l})$ were recorded for samples 3and 7 respectively. None of these was up to or exceeded the MPL of $100 \mathrm{mg} / \mathrm{l}$ (Table 4).

As for alkalinity, none of the chloride values for samples 1 to 7 (which ranged from $21.10-21.12 \mathrm{mg} / \mathrm{l}$ with a mean chloride standard deviation of $21.12 \pm 0.002 \mathrm{mg} / \mathrm{l}$ ) exceeded the MPL of $250 \mathrm{mg} / \mathrm{l}$. Hardness values for all processed samples ranged from $15-106 \mathrm{mg} / \mathrm{l}$ of which sample 4 recorded the highest hardness (106 mg/l) while the least (15 $\mathrm{mg} / \mathrm{l}$ ) was recorded by sample 7 . All samples recorded a mean hardness standard deviation of $53.3 \pm 32.72 \mathrm{mg} / \mathrm{l}$ and none of these values exceeded the MPL of $500 \mathrm{mg} / \mathrm{l}$. Related to this, are calcium and magnesium hardness. Based on results obtained, while calcium hardness for samples 1-7 ranged from $1.80-38.48 \mathrm{mg} / \mathrm{l}$ (with a mean calcium hardness standard deviation of $11.9 \pm 12.10 \mathrm{mg} / \mathrm{l}$ ), those for magnesium hardness ranged from $1.26-2.64 \mathrm{mg} / \mathrm{l}$ (with a mean magnesium hardness standard deviation of $1.7 \pm 0.51 \mathrm{mg} / \mathrm{l}$ ). Whereas none of the calcium hardness exceeded the MPL of $75 \mathrm{mg} / \mathrm{l}$, all magnesium hardness values exceeded the MPL of $0.20 \mathrm{mg} / \mathrm{l}$. Similarly, while the highest and lowest calcium hardness values were recorded for samples 4 and 7 respectively, those for magnesium hardness were recorded by samples 6 and 7respectively (Table 4).

The levels of phosphate, nitrate and sulphate for samples 1 - 7 (each having a mean phosphate, nitrate and sulphate standard deviation of $0.20 \pm 0.03 \mathrm{mg} / \mathrm{l}, 2.77 \pm 0.27 \mathrm{mg} / \mathrm{l}$ and $9.28 \pm 3.60 \mathrm{mg} / \mathrm{l}$ respectively) did not exceed the MPL values of $0.5 \mathrm{mg} / \mathrm{l}, 50 \mathrm{mg} / \mathrm{l}$ and $100 \mathrm{mg} / \mathrm{l}$ respectively. Also, dissolved oxygen (DO) and biological oxygen demand (BOD) values for samples 1-7 (which ranged from 5.2-6.8 and 2.8-3.8 and mean standard deviation of 5.9 \pm 0.58 and 3.04 \pm 0.51 respectively) did not exceed MPL World Health Organization values of 7.5 and 6.9 respectively. Overall, the water quality index of 489.04, 489.45, 482.93, 482.93, 811.67, 489.57 and 867.79 for samples 1, 2, 3, 4, 5, 6 and 7 respectively, each far exceeded MPL of 419.31 (Table 4).

\section{Discussion}

Access to safe drinking-water is essential to health, a basic human right and a component of effective policy for health protection [29]. The importance of water, sanitation and hygiene for health and development has been reflected in the outcomes of a series of international policy fora. These have included health-oriented conferences such as the International Conference on Primary Health Care, held in Alma-Ata, Kazakhstan (former Soviet Union), in 1978. They have also included water-oriented conferences such as the 1977 World Water Conference in Mar del Plata, Argentina, which launched the water supply and sanitation decade of 1981-1990, as well as the Millennium Development Goals adopted by the General Assembly of the United Nations (UN) in 2000 and the outcome of the Johannesburg World Summit for Sustainable Development in 2002. Most recently, the UN General Assembly declared the period from 2005 to 2015 as the International Decade for Action, "Water for Life." Access to safe drinking-water is important as a health and development issue at national, regional and local levels. In some regions, it has been shown that investments in water supply and sanitation can yield a net economic benefit, since the reductions in adverse health effects and health care costs outweigh the costs of undertaking the interventions. This is true for major water supply infrastructure investments through to water treatment in the home.

Experience has also shown that interventions in improving access to safe water favour the poor in particular, whether in rural or urban areas and this can be an effective part of poverty alleviation strategies. In 1983-1984 and in 1993- 
1997, the World Health Organization (WHO) published the first and second editions of the Guidelines for Drinkingwater Quality in three volumes as successors to previous WHO International Standards.

The spread of diseases through faecal contamination of water sources particularly in developing and under developed countries are a common phenomenon that has been well reported [30, 31, 32, 33, 34]. The quality and quantity of water for drinking and other purposes is failing in Nigeria due to inadequacy of treatment plants, direct discharge of untreated sewage into rivers and streams and ground wells as well as unproductive management of piped water distribution system [35, 36, 37]. An estimated 1.2 billion people drink unhygienic water which is the source of water related diseases that are responsible for about five to ten thousand teenage and adult deaths around the world today [38].

In this study, the untreated drinking water consumed by residents of Ofougbene-Izon community of Burutu local government area of Delta State harbored bacterial organisms of which Escherichia coli occurred in water samples collected from all the seven sites, followed by Enterobacter aerogenes which occurred in 6 (85.7\%) sites, Staphylococcus epidermidis featured in $4(57.0 \%)$ sites while Klebsiella pneumoniae occurred in $3(42.8 \%)$ sites. Presence of enteric coliforms especially Escherichia coli makes the water samples unsuitable for human consumption according to the guidelines set by WHO for the evaluation of bacteriological quality of drinking water [30]. Findings in this work are not similar to the report of some authors who isolated Klebsiella spp as the most predominant organism and Proteus mirabilis as the least occurring from well water sources [39]. The report of Ahmed et al. [15] was however related to our finding as they isolated Escherichia coli, Alkaligenes faecalis, Pseudomonas aeruginosa, Klebsiella spp and Proteus spp as the most occurring organisms in that decreasing order. The report of Sule et al. [40] however, did not support the findings of this study as they isolated Escherichia coli and Bacillus lentus as the least and most occurring organisms respectively in water from storage tanks. Some authors isolated Escherichia coli as the most occurring organism in groundwater and contaminated drinking water $[41,42]$.

The above are pathogenic organisms mainly of faecal origin. Any water source used for drinking or cleaning purpose should not contain any organism of faecal origin [43]. Presence of enteric coliforms especially Escherichia coli makes the water samples unsuitable for human consumption [30]. Contamination of the affected stations in this study may be attributed to drainage and flooding from contaminated surface water into unprotected well shafts [39]. Moreover, the isolation of the above named pathogens from the ground sources in this study poses a serious problem which calls for vigilance on the part of the Health authorities of Ofougbene Izon-Borotu community under study and the Delta State health authorities as it signals a possible future outbreak of water-borne diseases which may spread from this community to other neighboring riverine communities.

Results of the presumptive test in this study showed that all inoculated lactose broth tubes contained gas. Stations 1 (Labodozion ground well), Station 2 (Izon-borotu), Station 4 (Azenaware 1 well), Station 5 (Azenaware 2 well) and Station 6 (Ere-ebisingha well) recorded coliform loads of 90MPN/100 ml, 30MPN/100 ml, 160MPN/100 ml, $22 \mathrm{MPN} / 100 \mathrm{ml}$ and 50MPN/100 ml respectively. These values are higher than 20-50MPN/100 ml permissible limits set by the Standard Organization of Nigeria (SON) for drinking water. The results suggest that Station 4 recorded the highest level of contamination followed by Station 1 while the least contaminated was Station 5 . Only two stations (Stations 3 and 7) didn't record significant coliform contamination. The confirmatory and completed tests yielded results which established presence of coliforms. The presence of metallic green sheen on Eosin methylene Blue (EMB) agar and Gram negative bacilli on gram film viewed microscopically were pointers to presence of thermotolerant Escherichia coli.

The presence of a high MPN of coliforms in the drinking water samples indicates the presence of faecal contamination which could be due to the disposal of animal and human faeces directly into the river water [44]. Moreover, the type of organic waste entering the water body could influence the microbial flora that thrive there [45]. Compared to findings in this study, Ngwa and Chrysanthus [46] recorded 3-1100 MPN/100ml coliform count in their study. Some previous authors have reported 0-210 MPN/100ml counts [40], 6-161 MPN/100ml counts [47], > 1100 MPN/100ml counts [48].

Coliforms are considered to be microbiological indicators of water pollution (Sabae et al., 2014). These bacteria mostly belong to the family Enterobacteriaceae and include Escherichia coli, Enterobacter aerogenes, Klebsiella spp etc. Most coliforms are found in the intestinal tract of warm-blooded animals and enter the outside environment through the faeces of these animals $[49,50]$. These bacteria may not all be pathogenic themselves but serve as indicators of the presence of more pathogenic microorganisms which may also be present in animal faeces. Water contaminated by these pathogens may be ingested by humans which will lead to the occurrence of various enteric diseases [51].

The viable bacterial count of stored water (such as ground water) depends on the treatment the water source has received, handling of the stored water, the quality of the stored water source as well as the depth of the stored water 
[40]. Total aerobic plate count was performed to understand the overall microbiological condition of the samples and quantification of total faecal coliform was conducted to determine the associated risk with other possible pathogens. Water samples from the seven stations sampled contained aerobic bacterial loads ranging from $2.0 \times 10^{5}-7.0 \times 10^{5}$ $\mathrm{CFU} / \mathrm{ml}$ of which the lowest and highest bacterial loads were recorded in samples collected from stations 5/1 and stations 4/7 respectively (Table 3). Adebawore et al. [20] working on groundwater in Ile-Oluji, Ekiti State, recorded bacterial load range of $2.79 \times 10^{8}$ to $9.66 \times 10^{8} \mathrm{CFU} / \mathrm{ml}$ which comparatively, the bacterial loads are much higher than those recorded in this study. Other authors who worked on stored water in storage tanks recorded viable bacterial counts which ranged from $2.1 \times 10^{1}$ to $1.6 \times 10^{3} \mathrm{CFU} / \mathrm{ml}$ which are lower than counts recorded in this study [40]. Much higher counts should have been expected from storage tank water than ground water used in this study although Orji et al. [52] found that bacteriological qualities of ground water wells could be improved by storage.

Besides, the bacteriological analysis of the ground water samples from the community under study in this work to determine its pottability, analysis of the degree of pollution was further carried out by determining the physical and chemical statuses of the ground water samples. Hence, physic-chemical parameters such as $\mathrm{pH}$, temperature, dissolved oxygen (DO), biochemical oxygen demand (BOD), total hardness, calcium and magnesium hardness among others were analyzed and recorded. These physic-chemical features are very important in terms of sustaining the health of aquatic ecosystem $[53,54]$. Of all these parameters, DO is the most important as it provides information regarding the productivity, microbial activity, nutrient availability etc of an aquatic ecosystem [55].

In this study, groundwater collected from stations 3 and 7 recorded Dissolved Oxygen (DO) of $6.5 \mathrm{mg} / \mathrm{L} \mathrm{and} 6.8 \mathrm{mg} / \mathrm{L}$ which are above the SON and WHO maximum permissible limit of 6mg/l. Station 4 recorded DO of $6 \mathrm{mg} / \mathrm{L}$ suggesting that groundwater from all three stations are contaminated. Dissolved oxygen values give an estimate of the rate of microbial decomposition of organic wastes.

The colour of the groundwater samples except that from station 3 exceeded the maximum permissible limit (MPL) of 15. Other parameters which exceeded MPL were turbidity, total suspended solids (TSS) and magnesium hardness. Groundwater from station 4 stood out as the most polluted with turbidity, TSS and magnesium hardness values of 29 NTU, $12 \mathrm{mg} / \mathrm{L}$ and $2.43 \mathrm{mg} / \mathrm{L}$ respectively (station 4 was second to station 6 in terms of magnesium hardness. All the other parameters of $\mathrm{pH}$, electrical conductivity, TDS, alkalinity, chloride, phosphate, sulphate, total hardness, calcium hardness, magnesium hardness and BOD for all groundwater samples were within SON and WHO MPL. Overall, all groundwater samples recorded water quality indices much higher than the MPL with particular emphasis on samples from stations 5 and 7 which doubled the MPL.

The temperature of a water body plays an important role in the regulation of all biotic functions [56]. The measurement of BOD points to the amount of oxygen that is being used up by microbes to degrade organic waste. The higher the BOD value, the lower the DO values and vice versa. The $\mathrm{pH}$ really has no impact on human health except that it changes the taste of water and at the same time, it may lead to the formation of trihalomethanes which are toxic [50].

Hardness of water is the measure of the total concentration of calcium and magnesium ions expressed as calcium carbonate. Calcium hardness can be measured independently of total hardness as calcium is usually found in high concentration in water due to leaching from limestone deposits, gypsum deposits etc. Although, hardness has no effect on human or animal health, it is essential in the removal of toxic components in the water.

A total of seven water samples from seven different locations in Ofougbene community namely Labodo zion grounds, Leomoni quarters, Leomoni 1-Ibama well, Azenaware 1 quarters, Azenaware 2 quarters, Azenaware 3 quarters and Ereebisingha quarters were processed and analyzed in this study.

The $\mathrm{pH}$ values obtained in this study (5.8-6.1) were all below the Standard Organization of Nigeria (SON) acceptable range for drinking water which is 6.5-8.5. This outcome is similar in comparison to other trend (5.4-6.6) reported in Oghara water outlets in the Niger Delta. In this study the alkalinity of the samples fell short of the SON set limit. Turbidity is an important operational parameter and causes undesired tastes and odours and also affects the process of photosynthesis for agal growth, generally high turbidity values indicates a high concentration of total suspended solids. In this study both the turbidity and total suspended solids values were low.

The water was found to be soft except station 4 which was slightly hard with value of $106 \mathrm{mg} / \mathrm{L}$. The magnesium in the water samples analyzed was slightly above the set SON limit. High TDS in water samples commonly give objectionable or offensive taste. In this study, the values were recorded to be at $10.6-58.3 \mathrm{mg} / \mathrm{L}$ which is under the set limit of $500 \mathrm{mg} / \mathrm{L}$ by SON. Parameters including nitrate, chloride, sulphate and phosphate all fell under the set limits. The Electrical conductivity (EC) of the results obtained in this study fell under the permissible limit of 750 by SON. High EC is indicative 
of high dissolved solids. Also, both the EC and the total dissolved solids were low. These results are similar to the report of Adefusisoye et al. [57] in a related study.

\section{Conclusion}

All water samples were found to be contaminated with high MPN index which indicates the presence of great number of bacteria especially coliforms in the samples. Presence of $E$. coli in all samples confirmed the presence of fecal contaminants in them. E. coli is considered to be more closely associated with fecal contamination, The water quality index of each of the samples were found to be poor and not of standard.

The current study has revealed that the microbiological quality and water quality index of the groundwater samples under study are poor compared to the standard and this poses a health risk to the community and households that rely on them for domestic purposes. The information gathered by this study can benefit local authorities and provide insight into the state of the quality of water in the community and perhaps, encourage an alternative source of water supply such as pipe borne water. The quality of pipe borne water can be continously monitored to ensure that the people of the community have access to clean water for drinking and domestic purposes.

\section{Compliance with ethical standards}

\section{Acknowledgments}

We hereby appreciate laboratory staff of Microbiology Department of Western Delta University, Oghara, Nigeria. We also thankfully acknowledge Owina River Basin Authority, University of Benin, Nigeria for helping with the physicochemical analyses.

\section{Disclosure of conflict of interest}

We hereby state that there is no conflict of interest of any kind.

\section{References}

[1] Akbar A, Sitara U, Khan SA, Muhammad N and Khan MI. Drinking water quality and risk of waterborne diseases in the rural mountainous area of Azad Kashmir. Pakistan International Journal of Bioscience, 2013; 3:245-251.

[2] Wang L, He Y, Xia Y, Wang H and Liang S.Investigation of mechanism and molecular epidemiology of linezolidresistant Enterococcus faecalis in China. Information on Genetics Evolution, 2014; 14:160-169.

[3] Jarraud S, Mougel C, Thioulouse J, Lina G and Meugnier H. Relationships between Staphylococcus aureus genetic background, virulence factors, age groups (alleles) and human disease. Infectious Immunology 2002; 70:631-641.

[4] Herold M, Roberts DA, Gardner ME and Dennison PE. Spectrometry for urban area remote sensing. Science Direct Journal, 2004; 91:304-319.

[5] Feigin V, Brainin M, Breteler MMB, Martyn C, and Wolfe C.Teaching of neuroepidemiology in Europe: time for action. European Journal of Nerology, 2004; 11:795-799.

[6] Rosina G, Ferru MA, Alonso JL, Manzano JR and Calgua B. Molecular detection of pathogens in water-the pros and cons of molecular techniques. Water Review 2010; 44:4325-4329.

[7] Friedlander LR, Puri N, Schoonen MA and Wali Karzai A.The effect of pyrite on Escherichia coli in water: proofof-concept for the elimination of waterborne bacteria by reactive minerals. Journal of Water Health, 2015; 13:4253.

[8] Gomez-Alvarez V, Humrighouse BW, Revetta RP and Domingo JW.Bacterial composition in a metropolitan drinking water distribution system utilizing different source waters. Journal on Water Health, $2015 ; 1,57-62$.

[9] September SM, Els FA, Venter SN and Brözel VS. Prevalence of bacterial pathogens in biofilms of drinking water distribution systems. Journal of Water Health, 2007; 5:219-227.

[10] Tassadaq H, Roohi A, Munir S, Ahmed I and Khan J.Biochemical characterization and identification of bacterial strains isolated from drinking water sources of Kohat, Pakistan. African Journal of Microbioliogical Research, 2013; 7:1579-1590. 
[11] Mody RK, Meyer S, Trees E, White PL and Nguyen T.Outbreak of Salmonella enterica serotype I 4, 5, 12: infections: the challenges of hypothesis generation and microwave cooking. Epidemiological Infections, 2014; 142:10501060 .

[12] Pindi PK, Yadav PR and Shanker AS.Identification of Opportunistic Pathogenic Bacteria in Drinking Water Samples of Different Rural Health Centers and their Clinical Impacts on Humans. Biomedical Research international Article, ID 348250. 2013

[13] Baudart J, Coallier J, Laurent P and Prevost M.Rapid and sensitive enumeration of viable diluted cells of members of the family enterobacteriaceae in fresh water and drinking water. Applied Environmental Microbiology, 2002; 68:5057-5063.

[14] Shar AH, Kazi YF, Kanhar NA and Ghumro PB.Drinking water quality in Rohr City, Pakistan. African Journal of Biotechnology, 2010; 9(42):7102-7107.

[15] Ahmed T, Kanwal R, Tahir SS and Rauf N.Bacteriological analysis of water collected from different dams of Rawalpindi/Islamabad region in Pakistan. Pakistan Journal of Biological Science, 2004; 7:662-666.

[16] Khan FA, Ali J, Ullah R and Ayaz S.Bacteriological quality assessment of drinking water available at the flood affected areas of Peshawar. Toxicol \& Environ Chem, 2014; pp: 1448-1454.

[17] Collins CR and Lynes PM. Microbiology Method. 4th Edn, Butterworth Press, London, 1976; Pp 271-275.

[18] Mackie TJ and McCartney JE. Practical Medical Microbiology In: College, J.C., Dugluid, J.P., frasor,A.G. and Marmion, B.P, Edns. Church Living Stone Publication, 1989; 910pp.

[19] WHO 2011. Guidelines for Drinking water quality fourth edition. WHO Press, World Health Organisation, Geneva.

[20] Adebawore AA, Awokunmi EE, Akinyeye RO and Olanipekun EO. Physicochemical and bacteriological assessment of hand-dug well water from Ile-Oluji,Nigeria. American Journal of Innovative Research and Applied Sciences, 2016; 5:433-440.

[21] Olajubu FA and Ogunika 0. Assessment of the physico chemical and microbiological parameters of several borehole waters. International Journal of Pharmaceutical Science and Research, 2014; 3(6):886-894.

[22] Itah AY and Akpan CE. Potability of drinking water in an oil impacted community in Southern Nigeria. Journal of Applied Science and Environmental Management, 2005; 9(1):304-319.

[23] Bello 00, Osho A, Bankole SA and Bello TK.Bacteriological and physicochemical analysis of borehole and well water sources in Ijebu-Oda, Southwestern, Nigeria. IOSR Journal of Pharmaceutical and Biological Science, 2013; $8(2): 18-25$.

[24] SON, Nigerian standards for drinking water quality (NSDWQ), Industrial standards, SON. 2007; 554:1-14.

[25] Trivedy RK and Goel PK. Chemical and biological methods for water pollution studies, Environmental Publication, Karad, Maharashtra. 1986

[26] American Public Health Association, APHA. America water works association and water pollution control federation. Standard Method for Examination of water and waste water. 2000

[27] American Public Health Association, APHA. Standard methods for the examination of water and waste water. Washington DC. 2005

[28] Central for Pollution Control Board (2007). Guidelines for water quality monitoring, Delhi, India.

[29] WHO 2006. World Health Organization. Guidelines for drinking-water quality, first addendum to 2nd edn, Recommendations, 1.

[30] World Health Organization. Guidelines for drinking water quality. Health Criteria and other support information, 1996; pp18-97.

[31] Carrero-Colon M and Turco RF. 2006. Tracking Microbial Pathogens.

[32] World Health Organization. Guidelines for drinking water quality. Surveillance and Control of Community Supplies, 1997; 3(4):96-219.

[33] Lechevalier MW, Cawthon CD and Lee RG. Factors promoting survival of bacteria in chlorinated water supplies. Applied Environmental Microbiology, 1987; 88:649-554. 
[34] Olowe OA. Bacteriological quality of water samples in Osogbo metropolis. African Journal of Clinical and Experimental Microbiology, 2005; 6(3):219-222.

[35] UNEP, Annual Evaluation Report, 2001.

[36] Gbadegesin AS and Olorunfemi FB. Assessment of rural water supply management in selected areas of Oyo state, Nigeria. African Technology Studies Network Working Papers. 2007

[37] Aderibigbe SA, Awoyemi AO and Osagbemi GK. Availability, adequacy and quality of water supply in Ilorin metropolis, Nigeria. European Journal of Scientific Research, 2008; 23:528-536.

[38] Ahuja S. 2009. Handbook of water purity and quality, New York, USA. Academic Press Ainsworth, R. ed. 2004. Safe piped water: Managing microbial water quality in piped distribution systems. IWA Publishing, London, for World Health Organization, Geneva.

[39] Niba NR and Nchang C. Bacteriological analysis of well water sources in the Bambui student residential area. Journal of Water Resource and Protection, 2013; 5(11):1013-1017.

[40] Sule IO, Agbabiaka TO and Akomolafe AV. Bacteriological quality of water stored exteriorly in storage tanks. Research Journal of Environmental Science, 2011; 10:1-8.

[41] Aturama AO. Physical, chemical and bacterial analyses of groundwater in Ikere Township, Southwestern Nigeria. International Journal of Science and Technology, 2012; 2(5):301-307.

[42] Ekhaise FO and Omoigberale MO. Bacteriological and physicochemical qualities of Ebutte river in Ebutte Community, Uhunwonde Local Government Area, Edo State. Journal of Applied Science and Enviromental Management, 2011; 15(4):663-673.

[43] Bonde GJ. Bacterial indication of Water pollution. Advances in Aquatic Microbiology, Academic Press, London. 1977

[44] Frimpong JO, Amoaka EE and Nkoom M. Assessment of the physicochemical and microbial quality of water in KeNya stream at Babato-Kuma community in the Kintampo North Municipal assembly of brongahafo regionof Ghana. International Journal of Science and Technology Research, 2015; 4(6):405-411.

[45] Sumampouw OJ and Risjani Y. Bacteria as indicators of environmental pollution: Review. International Journal of Ecology, 2014; 4(6):251-258.

[46] Ngwa NR and Chrysanthus N. Bacteriological analysis of well water sources in the Bambui student residential area. Journal of Water Resource and Protection, 2013; 5:1013-1017.

[47] Antony RM and Renuga FB. Microbiological analysis of drinking water quality of Ananthanar channel of Kanyakumari district, Tamil Nadu, India. An Interdisciplinary Journal of Applied Science, 2012; 7(2):42-48.

[48] Gogoi A, Hujon A, Lyngwi MM and Syiem JN. Determination of the quality of Lukha river, Meghalaya on the basis of physicochemical and microbiological parameters. International Journal of Current Microbiological and Applied Sciences, 2016; 5(3):770-775.

[49] Thakur M, Negi S, Kumar A, Patil S, kumar A and Sharma N. Prevalence and characterization of water contamination indicator bacteria with special reference to coliforms from drinking water supply in Solan City of Himachal Pradesh. Biology for Ann. International Journal, 2012; 4(1):85-89.

[50] Mostafa AH, Al-Wasify RS, Sayed AM and Haroun BM. Microbiological and physicochemical evaluation of groundwater in Egypt. International Journal Environmental Science, 2013; 2(2):1-10.

[51] Saha ML, Nessa M, Khan MR, Islam MN and Hoque S. Bacteriological and physicochemical water quality of four ponds of Dhaka metropolis. Bangladesh Journal of Botany, 2012; 41(1):55-60.

[52] Orji MU, Nwokolo SO and Okoli I. Effect of palm oil mill effluent on soil microflora. Nigeria Journal of Microbiology, 2006; 20(2), 1026-1031.

[53] Ibrahim BU, Auta J and Balogun JK. An assessment of the physicochemical parameters of Kontagorareservoir, Niger State, Nigeria. Bayero Journal of Pure Applied Science, 2009; 2(1):64-69.

[54] Mbalassa M, Bagalwa JJM, Nshombo M and Kateyo ME. Assessment of physicochemical parameters in relation with fish ecology in Ishasha river and Lake Edward, Albertine rift valley, East Africa. International Journal Curriculum Microbiology and Applied Science, 2014; 3(6):230-244 
[55] Patil PN, Sawant DV and Deshmukh RN. Physicochemical parameters for testing of water- A review. International Journal of Env. Science, 2012; 3(3):1194-1207.

[56] Sabae SZ, El-Sheekh MM, Khalil MA, Elshouny, WAE and Badr HM. Seasonal and regional variation of physicochemical and bacteriological parameters of surface water inWi-Bahr, Egypt. World Journal Fish and Marine Science, 2014; 6(4):328-335.

[57] Adefusisoye AA, Awokunmi EE, Akinyeye RO and Olanipekun EO. Physico chemical and bacteriological assessment of hand dug well water from Ile-Oluji, Nigeria. American Journal of Innovative Research and Applied sciences, 2016; 3(1):433-440. 